\title{
Comparative Performance Evaluation of Metering Devices of Planters
}

\author{
A. Thakur, A. Waghmode*, A. S. Ghadge, A. B. Ghule and R. Patel \\ Department of Farm Power and Machinery, India \\ *Corresponding author
}

\begin{tabular}{|l|}
\hline \multicolumn{1}{l|}{} \\
\hline Key w o r d s \\
Evaluation, \\
Metering devices, \\
Planters, Miss \\
index, Feed index \\
\hline Article Info \\
\hline $\begin{array}{l}\text { Accepted: } \\
\text { 15 February 2020 } \\
\text { Available Online: } \\
\text { 10 March 2020 }\end{array}$ \\
\hline
\end{tabular}

\section{A B S T R A C T}

The comparative performance of inclined plate planter, raised bed planter \& pneumatic planter was evaluated at half and full hopper fill using $2.5 \mathrm{~km} / \mathrm{h} \& 3 \mathrm{~km} / \mathrm{h}$ speed alternatively for evaluation effects on miss index (MI), multiple index (MPI), feed index (QFI), cell fill percentage (CF) \& standard deviation (SD) with the agronomical properties of seeds, design, and fabrication of experimental setup and development of seed uniformity calculator. For generation of database seed uniformity of planter, an experimental setup of planter is designed and fabricated at the College of Agricultural Engineering, Jabalpur. The laboratory and workshop facilities of the Institute were used for development and fabrication of the machine.

\section{Introductions}

The present study deals with the agronomical properties of seeds, design, and fabrication of experimental setup and development of seed uniformity calculator. For generation of database seed uniformity of planter, an experimental setup of planter is designed and fabricated at the College of Agricultural Engineering, Jabalpur. The laboratory and workshop facilities of the Institute were used for development and fabrication of the machine.

\section{Materials and Methods}

\section{Theoretical seeding rate $\left(\mathbf{R}_{\text {st }}\right)$}

The number of seed planted per hectare was calculated by using the following relationship (Bakhtiari and Loghavi, 2009):

$\mathrm{R}_{\mathrm{st}}=\frac{10^{8}}{\mathrm{w} \times \mathrm{x}_{\mathrm{g}}}$

Where,

$\mathrm{R}_{\mathrm{st}}=$ Theoretical seeding rate, seed/ha;

$\mathrm{W}=$ Row width, $\mathrm{cm}$; and

$\mathrm{x}_{\mathrm{S}}=$ Seed spacing along the row, $\mathrm{cm}$.

\section{Seeding mass rate}

The total mass of seed planted per hectare expressed in $\mathrm{Mg} \mathrm{ha}^{-1}$ was calculated by using the following relationship (Bakhtiari and Loghavi, 2009): 
$\mathrm{R}_{\mathrm{sm}}=\left[\frac{\mathrm{M}}{\mathrm{w} \times \mathrm{x}_{\mathrm{g}}}\right] \times 100$

Where,

$\mathrm{R}_{\mathrm{sm}}=$ Seeding mass rate, $\mathrm{Mg} / \mathrm{ha}$;

$\mathrm{M}=$ Average mass of one seed, $\mathrm{g}$;

$\mathrm{W}=$ Row width, $\mathrm{cm}$; and

$\mathrm{x}_{\mathrm{s}}=$ Seed spacing along the row, $\mathrm{cm}$.

\section{Speed calculation}

Planter speed is very important for testing.
Controllable speeds are necessary for most of the operations performed with a tractor. They help give the farmer a larger degree of control in certain situations, such as field work. Planter speed was evaluated by timing and measuring the distance from the middle of the back tire.

Actual planter speed $(\mathrm{km} / \mathrm{h})=\frac{\text { Distance traveled }(\mathrm{m})}{\text { Time taken }(\mathrm{sec})} \times \frac{3600}{1000}$

John Deere 5310 Diesel (9 speed) nominal forward travel speeds

\begin{tabular}{|l|l|l|l|}
\hline Speed gear position & Gear & Speed $(\mathbf{m p h})$ & Speed $\mathbf{( k m / h )}$ \\
\hline \multirow{2}{*}{ A } & $1^{\text {st }}$ Gear & 1.32 & 2.13 \\
\hline & $2^{\text {nd }}$ Gear & 1.91 & 3.07 \\
\hline & $3^{\text {rd }}$ Gear & 2.60 & 4.19 \\
\hline \multirow{2}{*}{ B } & $1^{\text {st }}$ Gear & 3.12 & 5.02 \\
\hline & $2^{\text {nd }}$ Gear & 4.50 & 7.24 \\
\hline & $3^{\text {rd }}$ Gear & 6.14 & 9.88 \\
\hline \multirow{2}{*}{ C } & $1^{\text {st }}$ Gear & 8.56 & 13.78 \\
\hline & $2^{\text {nd }}$ Gear & 12.36 & 19.89 \\
\hline & $3^{\text {rd }}$ Gear & 16.86 & 27.13 \\
\hline
\end{tabular}

Source: Nebraska tractor tests report. Paper 2063, 1998.

\section{Field preparation}

To select the field for testing near the energy laboratory in the college of agriculture engineering JNKVV Jabalpur M.P.

Parches $20 \mathrm{~m}^{3}$ fine sand from the Suhagi
Jabalpur M.P.

Make a 15 X5X0.25 pit.

Fill all send in prepared appropriate size of pit.

Leveled bed with the help of manual leveler.

Field preparation is completed for testing. 
Specifications: 1) Inclined Plate Planter

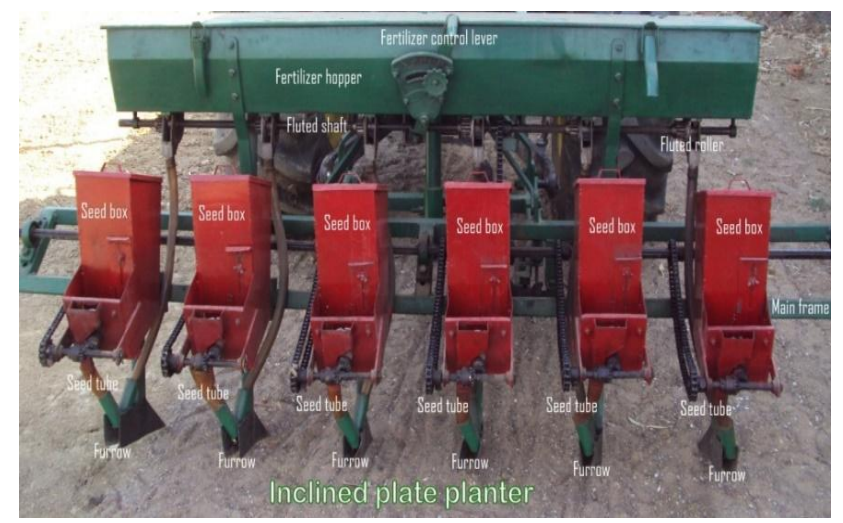

\begin{tabular}{|l|l|}
\hline Height $(\mathbf{m m})$ & $\mathbf{1 0 1 0}$ \\
\hline Distance between furrow openers & $300 \mathrm{~mm}$ \\
\hline No.of ground wheel & 1 \\
\hline No. of lugs on ground wheel & 12 \\
\hline Types of lugs & Flat pinte \\
\hline Number of rows in planter attachment & 6 (Maximum) \\
\hline Seed metering mechanism & Inclined plate with cell type \\
\hline Fertilizer metering & Fluted roller \\
\hline Furrow openers & Inverted T type \\
\hline
\end{tabular}

Specifications: Multi crop raised bed planter

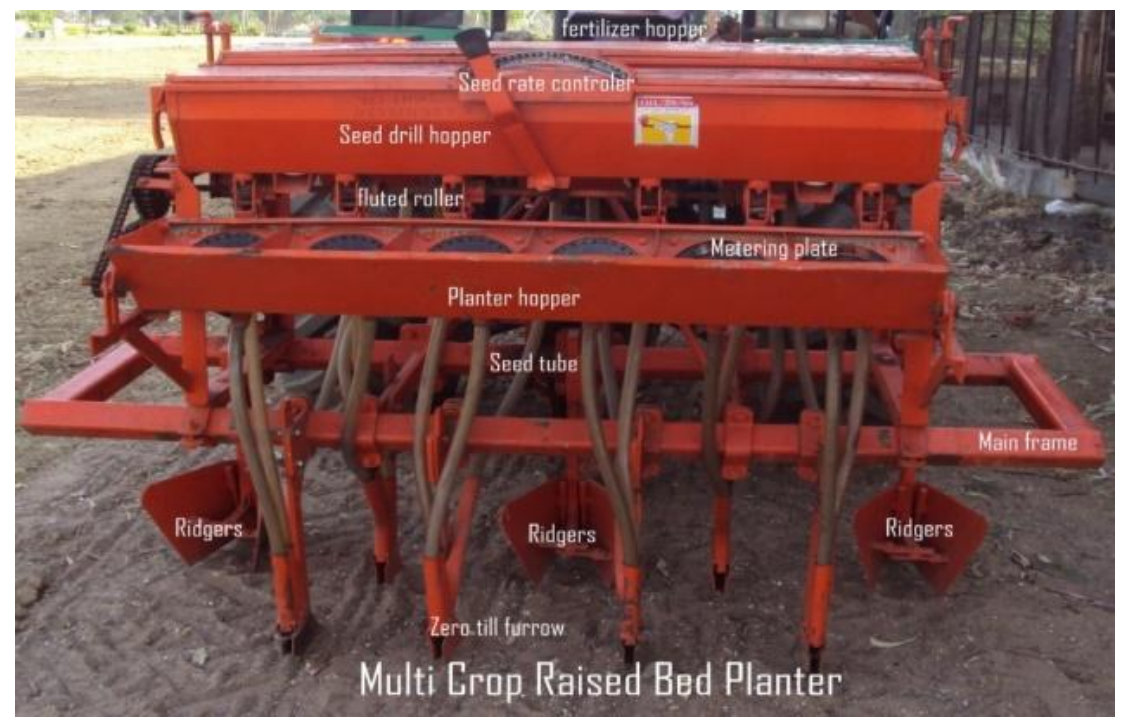




\begin{tabular}{|c|c|}
\hline Power source (hp) & 35 hp Tractor \\
\hline Length (mm) & 2500 \\
\hline Width (mm) & 1215 \\
\hline Height $(\mathbf{m m})$ & 1010 \\
\hline Distance between furrow openers & $300 \mathrm{~mm}$ \\
\hline No.of ground wheel & One \\
\hline No. of lugs on ground wheel & 12 \\
\hline Types of lugs & Flat Pointed \\
\hline Number of rows in planter attachment & 6 (Maximum) \\
\hline Seed metering mechanism & Inclined plate with cell type \\
\hline Fertilizer metering & Fluted roller \\
\hline Furrow openers & Inverted T type \\
\hline
\end{tabular}

\section{Pneumatic metering system}

Pneumatic metering systems are used for accurate metering of single seed in precision planters. In this system an aspirator sucks air from a seed drum where a particular negative air pressure (vacuum) is maintained. Negative air pressure holds the seeds in pockets on a plate until the seeds are conveyed up to the bottom where the suction pressure is cut-off and the seed are dropped into the seed tubes due to gravity.
Seed discs with different hole sizes are used for different kinds of seeds. Seed velocity at the delivery end is low, therefore, uniform seed distribution in the furrow is achieved.

Vacuum-type metering devices have 99 to $100 \%$ cell fill efficiency and 99 to $100 \%$ single seed picking efficiency if clean and graded seed are used.

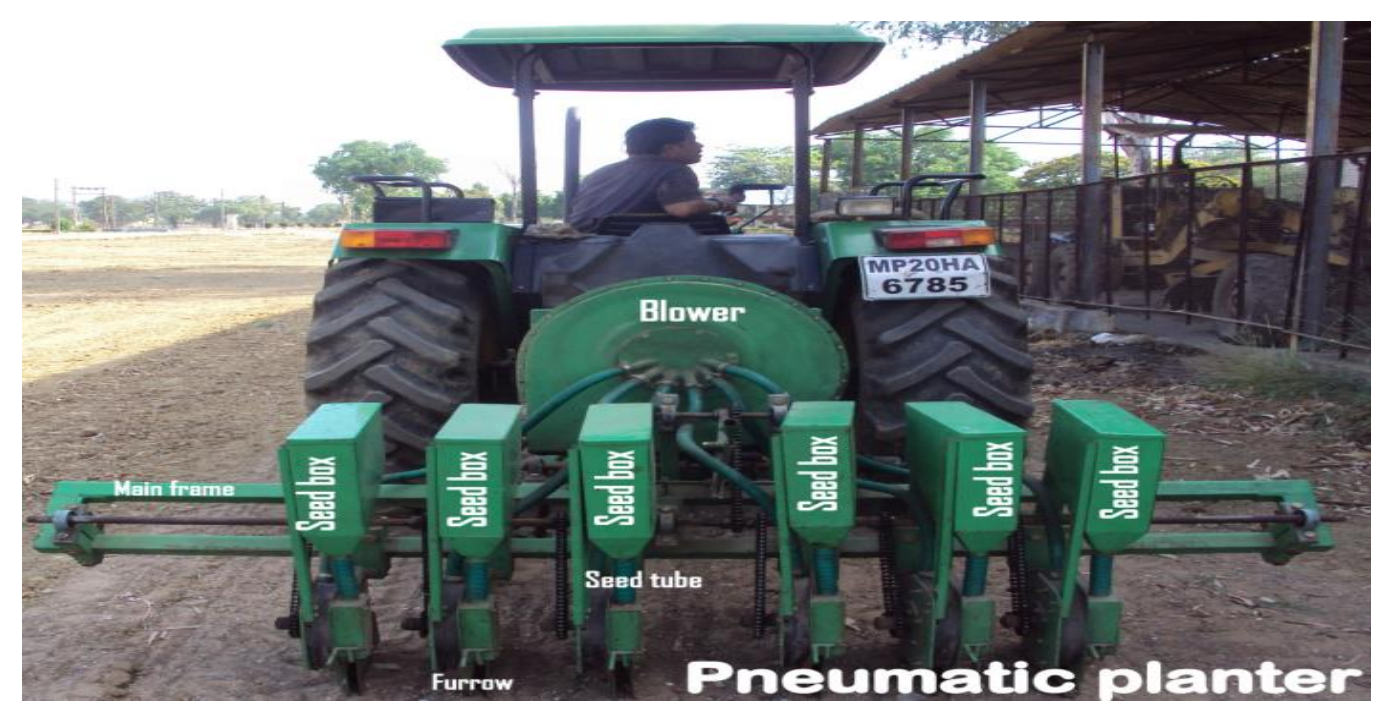

Details of seed plates used on the pneumatic planter 


\begin{tabular}{|c|c|c|c|c|}
\hline Seeds & $\begin{array}{c}\text { Recommended } \\
\text { seed spacing, mm }\end{array}$ & $\begin{array}{c}\text { No.of holes on } \\
\text { plate }\end{array}$ & $\begin{array}{c}\text { Seed-hole } \\
\text { diameter, mm }\end{array}$ & $\begin{array}{c}\text { Air suction } \\
\text { pressure,kPa }\end{array}$ \\
\hline Soybean & 50 & 16 & 4 & 3.5 \\
\hline Sorghum & 100 & 16 & 2 & 3.0 \\
\hline Pigeon pea & 100 & 16 & 2 & 3.5 \\
\hline Mustard & 150 & 16 & 1.5 & 2.0 \\
\hline Okra & 200 & 4 & 2 & 2.0 \\
\hline Maize & 300 & 6 & 4.5 & 4.5 \\
\hline Groundnut & 150 & 6 & 4.5 & 5.3 \\
\hline Cotton & 450 & 6 & 2.5 & 2.0 \\
\hline
\end{tabular}

Source: RNAM, 1991

\section{Results and Discussion}

\section{Effect of speed on performance of Half-} filled Hopper

\section{Inclined plate plant}

With increase in operating speed from 2.5 to 3 $\mathrm{km} / \mathrm{h}$, miss index (MI) and quality of feed index $(\mathrm{QFI})$ were increased from $17.19 \%$ to $20.46 \%$ and from $57.1 \%$ to $58.08 \%$ respectively but multiple index (MPI) and cell fill percentage (CF) were decreased from $25.71 \%$ to $21.47 \%$ and $101.61 \%$ to $99.73 \%$ respectively The reason may be that, the seed metering plates were getting less time to pick the seeds at $3 \mathrm{~km} / \mathrm{h}$ speed compared to 2.5 $\mathrm{km} / \mathrm{h}$. Standard deviation (SD) also increased from 5.96 to 6.05 due to increase in spacing. Staggenborget al., (2004), reported that as planter speed increases, efficiency of the seed metering process reduced.

\section{Multi crop raised bed planter}

With increase in operating speed from 2.5 to 3 $\mathrm{km} / \mathrm{h}$, miss index (MI) increased from $17.74 \%$ to $17.89 \%$, multiple index (MPI) decreased from $19.02 \%$ to $15.65 \%$. The metering disc did not get enough time to pick up seeds, resulting in higher miss index (MI) and low multiple index (MPI) at higher speed, (Singh et al., 2005) also found the same trend. Quality of feed index (QFI) increased from
$63.24 \%$ to $66.46 \%$, cell fill (CF) decreased from $95.18 \%$ to $94.94 \%$ and standard deviation (SD) increased from 5.13 to 5.74 .

\section{Pneumatic planter}

With increase in operating speed from 2.5 to 3 $\mathrm{km} / \mathrm{h}$, miss index (MI) increased from $15.48 \%$ to $15.51 \%$, multiple index (MPI) decreased from $4.1 \%$ to $3.93 \%$, quality of feed index (QFI) increased from $80.42 \%$ to $80.56 \%$, cell fill (CF) decreased from $99.87 \%$ to $99.57 \%$, standard deviation (SD) increased from 4.48 to 4.78. Singh et al., (2005) reported that miss index (MI) increases with increases in speed with lower vacuum pressure. At higher speeds, the metering disc did not get enough time to pick up seeds, resulting in higher miss index. The multiple index (MPI) on the other hand was low at higher speed but increase as the pressure was increased.

\section{Effect of speed at Full-filled hopper}

\section{Inclined plate planter}

With increase in operating speed from 2.5 to 3 $\mathrm{km} / \mathrm{h}$, miss index (MI) increased from $7.79 \%$ to $8 \%$, multiple index (MPI) decreased from $44.28 \%$ to $39.07 \%$.Singh et al., (2005) also reported similar findings. The quality of feed index (QFI) increased from $47.94 \%$ to $52.93 \%$, cell fill percentage (CF) decreased from $130.85 \%$ to $129.2 \%$. The reason may be 
that, the seed metering plates were getting less time to pick the seeds at $3 \mathrm{~km} / \mathrm{h}$ speed compared to $2.5 \mathrm{~km} / \mathrm{h}$, standard deviation (SD) increased from 4.53 to 5.11.Staggenborget al., (2004), found that increasing planter speed resulted in greater seed spacing and standard deviations (SD).

\section{Multi crop raised bed planter}

With increase in operating speed from 2.5 to 3 $\mathrm{km} / \mathrm{h}$, miss index (MI) increased from $13 \%$ to $14.35 \%$, multiple index (MPI) decreased from $32.23 \%$ to $24.89 \%$, quality of feed index (QFI) increased from $54.78 \%$ to $60.76 \%$, cell fill percentage $(\mathrm{CF})$ decreased from $100 \%$ to $99.37 \%$ The reason may be that, the seed metering plates were getting less time to pick up the seeds at $3 \mathrm{~km} / \mathrm{h}$ speed compared to 2.5 $\mathrm{km} / \mathrm{h}$. Standard deviation (SD) increased from 5.68 to 5.76 .

\section{Pneumatic planter}

With increase in operating speed from 2.5 to 3 $\mathrm{km} / \mathrm{h}$, miss index (MI), multiple index (MPI) and cell fill (CF) decreased from $15.26 \%$ to $15.13 \%, 6.73 \%$ to $3.93 \%$ and $99.21 \%$ to $96.56 \%$ and quality of feed index (QFI) increased from $78.01 \%$ to $80.56 \%$, respectively. The reason may be that, the seed metering plates were getting less time to pick the seeds at $3 \mathrm{~km} / \mathrm{h}$ speed compared to 2.5 $\mathrm{km} / \mathrm{h}$. Standard deviation (SD) increased from 4.53 to 4.92 .

\section{Effect of hopper fill on performance of planters at $2.5 \mathrm{~km} / \mathrm{h}$}

\section{Inclined plate planter}

With increase in hopper fill from half to full, miss index (MI) decreased from $17.19 \%$ to $7.79 \%$, multiple index increased (MPI) from $25.71 \%$ to $44.28 \%$, quality of feed index (QFI) decreased from $57.1 \%$ to $47.94 \%$, cell fill percentage (CF) increased from $101.61 \%$ to $130.85 \%$.The reason may be that, the shape of metering cell allowed two or more seeds at a time. Standard deviation (SD) decreased from 5.96 to 4.53 .

\section{Multi crop raised bed planter}

With increase in hopper fill from half to full, miss index (MI) decreased from $17.74 \%$ to 13 $\%$, multiple index (MPI) increased from $19.02 \%$ to $32.23 \%$, quality of feed index (QFI) decreased from $63.24 \%$ to $54.78 \%$, cell fill $(\mathrm{CF})$ increased from $95.18 \%$ to $100 \%$. The reason may be that, the shape of metering cell/seed hole was not allowing two or more seeds at a time. Standard deviation (SD) decreased from 5.68 to 5.13 .

\section{Pneumatic planter}

With increase in hopper fill from half to full, miss index (MI) decreased from $15.48 \%$ to $15.26 \%$, multiple index (MPI) increased from $4.1 \%$ to $6.73 \%$, quality of feed index (QFI) decreased from $80.42 \%$ to $78.01 \%$ and cell fill (CF) decreased from $99.87 \%$ to $99.21 \%$ The reason may be that, the pneumatic planter metering device based on suction pressure thus the multiple index (MPI) was less compared to the inclined plate planter and multi crop planter. Standard deviation (SD) increased from 4.48 to 4.53 .

\section{Effect of Hopper Fill on performance of planters at $2.5 \mathrm{~km} / \mathrm{h}$}

\section{Inclined plate planter}

With increase in hopper fill from half to full, miss index (MI) decreased from $20.46 \%$ to 8 $\%$, multiple index (MPI) increased from $21.47 \%$ to $39.07 \%$, quality of feed index (QFI) decreased from $58.08 \%$ to $52.93 \%$, cell fill (CF) increased from $99.73 \%$ to $129.2 \%$ The reason may be that, the shape of metering cell was allowing two or more seeds at a time. Standard deviation (SD) decreased from 6.05 
to 5.11 .

\section{Multi crop raised bed planter}

With increase in hopper fill from half to full, miss index (MI) decreased from $17.89 \%$ to $14.35 \%$, multiple index (MPI) increased from $15.65 \%$ to $24.89 \%$, quality of feed index (QFI) decreased from $66.46 \%$ to $60.76 \%$, cell fill (CF) increased from $94.94 \%$ to $99.37 \%$ The reason may be that, the shape of metering cell/seed hole was not allowing two or more seeds at a time. Standard deviation (SD) decreased from 5.76 to 5.74 .
Pneumatic planter: With increase in hopper fill from half to full, miss index (MI) decreased from $15.51 \%$ to $15.13 \%$, multiple index (MPI) increased from $3.93 \%$ to $4.4 \%$, quality of feed index (QFI) decreased from $80.56 \%$ to $80.47 \%$, cell fill (CF) decreased from $99.57 \%$ to $96.56 \%$ The reason may be that, the pneumatic planter metering device based was on suction pressure, thus the multiple index (MPI) was very less compared to the inclined plate planter and multi crop planter. Standard deviation (SD) increased from 4.78 to 4.92 .

Table.1

\section{Comparative results of the field experiments of planters at forward speed $2.5 \mathrm{~km} / \mathrm{h}$ with hopper fill- half}

\begin{tabular}{|c|c|c|c|c|c|c|c|c|c|c|c|c|}
\hline \multirow{2}{*}{$\begin{array}{c}\text { Particulars } \\
\text { Furrow }\end{array}$} & \multicolumn{3}{|c|}{ Inclined Plate Planter } & \multirow[t]{2}{*}{ Mean } & \multicolumn{3}{|c|}{ Raised Bed Planter } & \multirow[t]{2}{*}{ Mean } & \multicolumn{3}{|c|}{ Pneumatic Planter } & \multirow[t]{2}{*}{ Mean } \\
\hline & 1 & 2 & 3 & & 1 & 2 & 3 & & 1 & 2 & 3 & \\
\hline $\begin{array}{c}\text { No. of } \\
\text { Distances }\end{array}$ & 35.67 & 38.33 & 36 & 36.67 & 35.33 & 35.3 & 40 & 36.88 & 26.3 & 26 & 29.67 & 27.32 \\
\hline $\begin{array}{c}\text { Average } \\
\text { (Distances) }\end{array}$ & 8.52 & 7.87 & 7.64 & 8.01 & 7.95 & 8.4 & 7.59 & 7.98 & 10 & 10.52 & 9.69 & 10.07 \\
\hline $\begin{array}{l}\text { Standard } \\
\text { Deviation }\end{array}$ & 6.49 & 6.04 & 5.55 & 6.03 & 5.55 & 6.53 & 5.73 & 5.94 & 4.72 & 5.54 & 6.13 & 5.46 \\
\hline No. of Misses & 5 & 5 & 4 & 4.67 & 5.67 & 5.6 & 6 & 5.76 & 1.33 & 2.67 & 4 & 2.67 \\
\hline $\begin{array}{l}\text { No. of } \\
\text { Accumulation }\end{array}$ & 5.33 & 6.67 & 5.33 & 5.78 & 6 & 4.6 & 8.3 & 6.30 & 2.33 & 3 & 5.67 & 3.67 \\
\hline $\begin{array}{l}\text { Coefficient of } \\
\text { Variance }\end{array}$ & 0.76 & 0.77 & 0.73 & 0.75 & 0.7 & 0.778 & 0.75 & 0.74 & 0.47 & 0.53 & 0.63 & 0.54 \\
\hline $\begin{array}{l}\text { Planting } \\
\text { Errors }\end{array}$ & 1.75 & 1.84 & 1.57 & 1.72 & 2.17 & 1.92 & 2.53 & 2.21 & 0.94 & 1.48 & 2.21 & 1.54 \\
\hline Cell fill \% & 100.69 & 102.07 & 102.07 & 101.61 & 98.33 & 92.78 & 94.44 & 95.18 & 99.2 & 96 & 109.6 & 101.60 \\
\hline
\end{tabular}


Comparative results of the field experiments of planters at forward speed $3 \mathrm{~km} / \mathrm{h}$ with hopper fill -half

\begin{tabular}{|l|l|l|l|l|l|} 
Particulars & Inclined Plate Planter & Mean & Raised Bed Planter & Mean & Pneumatic Planter \\
\hline
\end{tabular}

\begin{tabular}{|c|c|c|c|c|c|c|c|c|c|c|c|c|}
\hline Furrow & 1 & 2 & 3 & & 1 & 2 & 3 & & 1 & 2 & 3 & \\
\hline $\begin{array}{c}\text { No. of } \\
\text { Distances }\end{array}$ & 33 & 33.67 & 32.67 & 33.11 & 39.7 & 38.3 & 41.3 & 39.77 & 32.67 & 31.3 & 28.6 & 30.86 \\
\hline $\begin{array}{l}\text { Average } \\
\text { Distances) }\end{array}$ & 8.61 & 8.59 & 9.27 & 8.82 & 7.8 & 8.14 & 8.13 & 8.02 & 9.56 & 10.22 & 10.57 & 10.12 \\
\hline $\begin{array}{l}\text { Standard } \\
\text { Deviation }\end{array}$ & 5.13 & 6.53 & 6.49 & 6.05 & 5.09 & 6.801 & 5.39 & 5.76 & 5.44 & 5.35 & 5.39 & 5.39 \\
\hline $\begin{array}{l}\text { No. of } \\
\text { Misses }\end{array}$ & 3.67 & 5.67 & 5.33 & 4.89 & 4.33 & 7.3 & 6.33 & 5.99 & 4 & 2 & 3 & 3.00 \\
\hline $\begin{array}{l}\text { No. of } \\
\text { Accumulat } \\
\text { ion }\end{array}$ & 2.33 & 5 & 3.33 & 3.55 & 3 & 7 & 2.33 & 4.11 & 3 & 3.33 & 3.67 & 3.33 \\
\hline $\begin{array}{l}\text { Coefficient } \\
\text { of } \\
\text { Variance }\end{array}$ & 0.6 & 0.76 & 0.7 & 0.69 & 0.65 & 0.84 & 0.66 & 0.72 & 0.57 & 0.53 & 0.509 & 0.54 \\
\hline $\begin{array}{c}\text { Planting } \\
\text { Errors }\end{array}$ & 1.1 & 1.91 & 1.6 & 1.54 & 1.21 & 2.45 & 1.38 & 1.68 & 1.45 & 1.15 & 1.58 & 1.39 \\
\hline Cell fill \% & $\begin{array}{c}100.8 \\
3 \\
\end{array}$ & 98.35 & 100 & 99.73 & 93.04 & 93.67 & 98.1 & 94.94 & 99.33 & 98.67 & 100 & 99.33 \\
\hline
\end{tabular}

\begin{tabular}{|c|c|c|c|c|c|c|c|c|c|c|c|c|}
\hline \multicolumn{13}{|c|}{$\begin{array}{c}\text { Comparative results of the field experiments of planters at forward speed } 2.5 \mathrm{~km} / \mathrm{h} \text { with } \\
\text { hopper fill- full }\end{array}$} \\
\hline Particulars & \multicolumn{3}{|c|}{$\begin{array}{l}\text { Inclined Plate } \\
\text { Planter }\end{array}$} & \multirow[t]{2}{*}{ Mean } & \multicolumn{3}{|c|}{$\begin{array}{l}\text { Raised Bed } \\
\text { Planter }\end{array}$} & \multirow[t]{2}{*}{ Mean } & \multicolumn{3}{|c|}{$\begin{array}{l}\text { Pneumatic } \\
\text { Planter }\end{array}$} & \multirow[t]{2}{*}{ Mean } \\
\hline Furrow & 1 & 2 & 3 & & 1 & 2 & 3 & & 1 & 2 & 3 & \\
\hline $\begin{array}{l}\text { No. of } \\
\text { Distances }\end{array}$ & 60.6 & 62.67 & 57 & 60.09 & 42.66 & 44 & 41.67 & 42.78 & 31 & 28.67 & 29.67 & 29.78 \\
\hline $\begin{array}{c}\text { Average } \\
\text { (Distances) }\end{array}$ & 4.973 & 5.18 & 5.59 & 5.25 & 7.183 & 6.79 & 7.36 & 7.11 & 10.19 & 10.56 & 10.12 & 10.29 \\
\hline $\begin{array}{l}\text { Standard } \\
\text { Deviation }\end{array}$ & 4.357 & 4.78 & 4.45 & 4.53 & 4.781 & 5.32 & 5.28 & 5.13 & 4.35 & 4.69 & 4.54 & 4.53 \\
\hline No. of Misses & 2.66 & 3.33 & 3 & 3.00 & 2.33 & 4.33 & 4.67 & 3.78 & 1.67 & 2 & 1.33 & 1.67 \\
\hline $\begin{array}{l}\text { No. of } \\
\text { Accumulation }\end{array}$ & 18.66 & 24 & 15.67 & 19.44 & 10.66 & 9 & 8 & 9.22 & 2 & 1.33 & 1 & 1.44 \\
\hline $\begin{array}{l}\text { Coefficient of } \\
\text { Variance }\end{array}$ & 0.876 & 0.92 & 0.8 & 0.87 & 0.674 & 0.78 & 0.72 & 0.72 & 0.42 & 0.44 & 0.45 & 0.44 \\
\hline $\begin{array}{c}\text { Planting } \\
\text { Errors }\end{array}$ & 2.63 & 2.63 & 1.98 & 2.41 & 1.99 & 1.99 & 1.99 & 1.99 & 0.8 & 0.79 & 0.53 & 0.71 \\
\hline Cell fill \% & 132.23 & 130.58 & 129.75 & 130.85 & 99.37 & 100 & 100.63 & 100.00 & 100 & 98.67 & 98 & 98.89 \\
\hline
\end{tabular}




\begin{tabular}{|c|c|c|c|c|c|c|c|c|c|c|c|c|}
\hline \multicolumn{13}{|c|}{$\begin{array}{c}\text { Comparative results of the field experiments of planters at forward speed } 3 \mathrm{~km} / \mathrm{h} \text { with hopper } \\
\text { fill- full }\end{array}$} \\
\hline Particulars & \multicolumn{3}{|c|}{ Inclined Plate Planter } & \multirow[t]{2}{*}{ Mean } & \multicolumn{3}{|c|}{ Raised Bed Planter } & \multirow[t]{2}{*}{ Mean } & \multicolumn{3}{|c|}{ Pneumatic Planter } & \multirow[t]{2}{*}{ Mean } \\
\hline Furrow & 1 & 2 & 3 & & 1 & 2 & 3 & & 1 & 2 & 3 & \\
\hline No. of Distances & 53 & 55 & 55 & 54.33 & 32.33 & 33.67 & 40 & 35.33 & 28.67 & 25.67 & 28.67 & 27.67 \\
\hline $\begin{array}{c}\text { Average } \\
\text { (Distances) }\end{array}$ & 5.76 & 5.35 & 5.79 & 5.63 & 7.76 & 9.12 & 7.61 & 8.16 & 10.3 & 11.17 & 10.04 & 10.50 \\
\hline $\begin{array}{l}\text { Standard } \\
\text { Deviation }\end{array}$ & 5.27 & 5 & 5.06 & 5.11 & 5.08 & 6.79 & 5.36 & 5.74 & 4.93 & 4.94 & 4.89 & 4.92 \\
\hline No. of Misses & 3.3 & 3 & 3 & 3.10 & 3.33 & 7 & 5 & 5.11 & 2.67 & 2.67 & 2 & 2.45 \\
\hline $\begin{array}{c}\text { No. of } \\
\text { Accumulation }\end{array}$ & 16.3 & 15.33 & 14 & 15.21 & 2.67 & 4 & 8.67 & 5.11 & 1 & 1.67 & 1.33 & 1.33 \\
\hline $\begin{array}{c}\text { Coefficient of } \\
\text { Variance }\end{array}$ & 0.91 & 0.96 & 0.87 & 0.91 & 0.66 & 0.74 & 0.72 & 0.71 & 0.48 & 0.44 & 0.49 & 0.47 \\
\hline Planting Errors & 2.24 & 2.01 & 1.87 & 2.04 & 1.22 & 2.14 & 2.24 & 1.87 & 0.87 & 1.14 & 0.79 & 0.93 \\
\hline Cell fill \% & 132.23 & 131.4 & 123.97 & 129.20 & 99.37 & 101.27 & 97.47 & 99.37 & 100.67 & 100 & 98.67 & 99.78 \\
\hline
\end{tabular}

Conclusion of the study are as follows:

This chapter deals with the summary of the study, its conclusive remarks and identified suggestion for future works.

1. The moisture content of seeds was measured and found the moisture content of soybean $9.10 \%$ standard deviation was 0.152 and coefficient of variance was 0.018 .

2. The bulk density of soybean seeds was $0.718 \mathrm{~g} / \mathrm{cm}^{3}$ standard deviation was 0.006 .

3. The 1000 grain weight of soybean was measured and found the sample weight is $127.8 \mathrm{~g}$.

4. Germination percentage of soybean seed varieties of JS 97-52 was $90.4 \%$ and after testing germination percentage was $89.6 \%$.

5. Seed damaged percentage under laboratory testing was found $0.8 \%$. However, mechanical damage to seeds due to metering device was negligible.

6. Soybean seed planted per hectare was 6 , 66,667 seeds and theoretical seed rate was $80 \mathrm{~kg} / \mathrm{ha}$.

7. Misses was higher for raised bed planter (5.99) and inclined plate planter (4.89) than pneumatic planter (3.00) and accumulation was higher in case of raised bed planter (4.11) while inclined plate planter (3.55) then pneumatic planter (3.33) at condition of half hopper filling with speed $3 \mathrm{~km} / \mathrm{h}$.

8. Vacuum type metering devices in pneumatic planter have 99 to $100 \%$ cell fill efficiency and 99 to $100 \%$ single seed picking efficiency is eliminated in pneumatic system. There is no effect of hopper filling.

\section{References}

Anantachar, M. PrasannaKumar, G.V. Guruswamy, T. (2010). Neural network prediction of performance parameters of an inclined plate seed metering device and its reverse mapping for the determination of optimum design and operational parameters. Computer and Electronics in Agriculture 72:87-98.

Afzalinia, S., Shaker, M. and Zare, E. (2006). Performance evaluation of common grain drills in Iran. Canadian Biosystems Engineering/Le génie des biosystèmes au Canada (48): 2.39 2.43 . 
Antoni, G. R., W. D. Beversdorf and V. A. Dirks (1965). Row width and seeding rate performance of indeterminate, semideterminate and determinate wheat. J. Prod. Agric 4:391-395.

Bakhtiari, M. R. and M. Loghavi (2009). Development and evaluation of an innovative garlic clove precision planter. J. Agric. Sci. Technol, 11: 125136.

Bahri, A. (1995).Modulating wheat seeding rate for site specific crop management . Phd Dissertation, University of Nebraska, Lincoln.

Bainer, R., A. A. Kepner and E. L. Barger (1960). Principle of farm machinery. John Wiley and Sons, New York.

Basnet, J. and J. F. Power (1974). Effects of plant and row spacing on dryland soybean yield and water-use-efficiency. Agron. J 74:851-854.

Chauhan, A. M. and K. Ramesh (1972). Review of research and development in seed cum fertilizer drills in India and rates for further work. J. Agricultural Engineering, 9 (3): 31-43.
Chen, Y., Tessier, S. and Irvine, B. (2004). Drill and crop performances as affected by different drill configurations for notill seeding. Soil \& Tillage Research 77(2): 147-155.

Doan, V., Chen, Y. and Irvine, B. (2005). Effect of residue type on the performance of no-till seeder openers. Canadian Biosystems Engineering 47: 2.29-2.35

Drummond, P.E., (2002). Variable rate drive. United states patent. No US2002/0178981.

Dubey, A. K. (2003). Design of sowing machine. Teaching material for training on computer aided design and design methodology for agricultural machinery. Technical bulletin no CIAE/AMD/2003/296: 92-102.

Dubey, A. K. (2003). Testing and seeding of planting and seeding equipment, Teaching material for Instrumentation and testing of agricultural machinery, CIAE/AMD/2003/303: 141-151.

\section{How to cite this article:}

Thakur, A., A. Waghmode, A. S. Ghadge, A. B. Ghule and Patel, R. 2020. Comparative Performance Evaluation of Metering Devices of Planters. Int.J.Curr.Microbiol.App.Sci. 9(03): 1906-1915. doi: https://doi.org/10.20546/ijcmas.2020.903.221 